\title{
Gender dan identitas dalam sastra di mata remaja
}

\section{Gender and identity of teenager in the literature from teens' perspective}

\author{
Sandya Rani Yunita \& Wening Udasmoro \\ Fakultas Ilmu Budaya, Universitas Gadjah Mada, Yogyakarta \\ Jalan Nusantara 1, Bulaksumur, Catur Tunggal, DIY 55281, Indonesia \\ E-mail: sandya.fib@ugm.ac.id \& udasmoro@ugm.ac.id
}

\begin{abstract}
Young adult literature is one of the literary genre which implied teenage audience or adolescent. It is often confused with what can be exactly considered as children literature. Adolescence as a group of age, is placed in between childhood and adult people. Through an adolescent fiction, Lupus, this research sees gender as an effect and as a tool which could influence the adolescent's identity. Based on theory of social practice, the things that are usually done by the teenagers in everyday life will be considered as a common sense although it is opposed to normative matters, such as a choice of their gender role. Adolescent readers in this case, are not fully aware of gender and identity, but they define those things related to the construction of sociocultural context.
\end{abstract}

Keywords: literature, adolescence, Lupus, gender, identity

\begin{abstract}
Abstrak
Karya sastra remaja adalah salah satu genre sastra yang melibatkan remaja, baik sebagai pembaca maupun penulisnya. Terkadang karya sastra remaja dianggap sejajar dengan karya sastra yang diperuntukkan bagi anak-anak. Remaja sebagai kelompok umur, diletakkan di antara kelompok anak-anak dan orang dewasa. Melalui fiksi remaja Lupus, penelitian ini melihat gender sebagai efek dan alat yang bisa mempengaruhi identitas remaja. Berdasarkan teori social practice, hal yang biasa dilakukan oleh remaja dalam keseharian kemudian akan dianggap wajar meskipun berlawanan dengan hal-hal normatif, misalnya dalam pilihan peran gender mereka. Pembaca remaja dalam hal ini tidak sepenuhnya sadar akan gender dan identitas namun mendefinisikan kedua hal tersebut berkaitan dengan konstruksi konteks sosial-kulturalnya.
\end{abstract}

Kata kunci: karya sastra, remaja, Lupus, gender, identitas

\section{Pendahuluan}

"When adults say, "Teenagers think they are invincible!" with that sly, stupid smile on their faces, they don't know how right they are. We need never be hopeless, because we can never be irreparably broken. We think that we are invincible because we are. (John Green (2005), Looking for Alaska)

Kutipan tersebut secara tidak langsung mewakilkan keadaan remaja masa kini. Dalam lingkungan masyarakat, definisi remaja acapkali membingungkan. Remaja dianggap terlalu besar sebagai anakanak namun juga belum pantas disebut sebagai orang dewasa. Udasmoro (2014:1) pun menuliskan bahwa remaja sebagai kategori sosial lebih sering tidak mendapatkan perhatian dalam karya sastra lebih kerap menjadi genre yang marjinal- dan disejajarkan dengan karya popular yang dianggap tidak memiliki nilai estetika tinggi.

Masa remaja mau tidak mau menjadi tahapan dalam kehidupan seseorang yang tidak dapat dihindari. Dengan rentang usia mulai dari 12-18 tahun (Mackey 2011:4) remaja yang sering disebut adolescent atau young adult dengan rentang usia "late adolescence aged between 18 and 22", diposisikan di antara anak-anak dan dewasa dan dari segi sastra pun kurang mendapat perhatian khusus. Berbeda jika dibandingkan dengan sastra anak, "sebagian besar penulis atau orang tua sebagai pembaca akan memiliki keyakinan bahwa genre sastra anak masih layak untuk dibaca, didiskusikan serta dipikirkan,” jelas Hunt (2005:2). Sastra remaja sebagai genre sering dilihat 
sebagai karya sastra yang diperuntukkan bagi orang dewasa, dengan intrik dan drama percintaan atau konflik yang belum tentu dialami remaja pada umumnya.

Sastra Indonesia mengalami perkembangan sastra remaja dalam satu dekade ini secara signifikan meskipun dapat dikatakan bahwa, sastra remaja Indonesia masih kurang dalam hal kuantitas apabila dibandingkan dengan sastra remaja yang ada di Eropa maupun Amerika. Beberapa penulis menyebut diri mereka penulis teenlit atau chicklit namun karena kemasan dan konten cerita, karya tersebut biasanya hanya dinikmati oleh remaja putri saja dan masih belum bisa mendorong remaja putra untuk duduk dan ikut membaca. Ada diversivikasi yang bersifat oposisitif antara ketertarikan remaja laki-laki dan perempuan dalam penulisan sastra remaja. Ruang berekspresi terbuka untuk keduanya tetapi ruang tersebut digunakan oleh remaja perempuan daripada oleh remaja laki-laki. Persoalan konsumsi terhadap sastra remaja juga lebih cenderung memberikan ruang pada karya sastra remaja terjemahan yang lebih menjelaskan persoalan lifestyle bagi mereka yang mengkonsumsinya. Dari segi penerbitan, sastra bisa dikatakan lebih sedikit frekuensinya daripada sastra dewasa karena permintaan pasar yang lebih menginginkan karya sastra bagi khalayak dewasa. Contoh konkretnya pada karya-karya Darwis Tere Liye yang ditujukan mulai dari anakanak, remaja hingga pembaca dewasa.

Apabila penerbit menjadi tolok ukur strategi pasar di masyarakat, beberapa penerbit yang mulai menunjukkan greget sastra remaja sedang berkembang di Indonesia adalah penerbit Gagasmedia, Bukune, IndonesiaTera, Transmedia dan Dar Mizan yang mengklaim sebagai penerbit novel populer dan buku remaja. Hal ini terlihat dari situs-situs mereka yang menampilkan katalog sampul novel dan buku berwarna-warni khas remaja serta kompetisi penulisan cerita fiksi/novel remaja.

Berkaitan dengan cerita fiksi atau novel remaja, remaja Indonesia tahun 1986 sampai era 90-an pasti kenal dengan tokoh Lupus. Remaja berjambul yang digambarkan senang mengunyah permen karet ini, menjadi idola baru dan ikon identitas remaja sekolah menengah atas pada masa itu. Setelah kemunculan pertama kalinya dalam cerpen di majalah Hai (majalah remaja yang berisi penelitian tentang musik, hobi, film, dan rekreasi), Lupus menjadi tokoh utama yang ditampilkan oleh sang penulis (Hilman) ke dalam banyak novel dengan menggunakan namanya, contohnya Lupus I: Tangkaplah Daku Kau Kujitak, Lupus n' Work, Lupus Milenia, Bangun Dong, Lupus, dan lainnya. Terhitung ada lebih dari 29 judul novel Lupus, Lupus ABG, dan Lupus Kecil yang ditulis Hilman Hariwijaya dan Boim LeBon.

Udasmoro (2014:5) melihat perbedaan konten cerita pada novel remaja era tahun 1970 sampai 1980-an dengan era Lupus. Pada era sebelumnya karya remaja banyak menceritakan perjuangan percintaan dua sejoli sementara dengan adanya ikon Lupus, ada pencarian identitas yang sedang dibangun terkait dengan remaja. Penggunaan model rambut, pakaian, dan karakter tokoh utama Lupus dalam film menjadi pemandangan sehari-hari di kehidupan remaja pada waktu itu. Udasmoro (2014:6) menambahkan hal ini sesuai dengan teori social practice dalam pandangan Pierre Bordieu, bahwa praktik sosial yang dilakukan secara terus-menerus dalam keseharian menjadi sebuah hal yang wajar (common sense).

Maskulinitas yang diusung oleh tokoh Lupus baik dalam novel maupun film tergambar jelas dan dipandang sesuai dengan kondisi sosial Indonesia pada masa itu. Suzie Handajani (2010:68-69) dalam disertasinya menunjukkan bagaimana dominasi laki-laki kuat berakar pada masa transisi masyarakat Indonesia yang kerap diperlihatkan melalui konflik di antara mereka (laki-laki) sendiri, terutama di bidang politik. Sejarah Indonesia lebih sering menampilkan sosok maskulin dan lakilaki sebagai pahlawan nasional atau musuh bersama, baik dalam arsip maupun buku sejarah yang beredar di pasaran. Meskipun secara fakta, laki-laki merupakan sosok dominan pada masa itu, Handajani (2010:69) menambahkan bahwa mereka merupakan representasi sosial politik yang tidak bergender dan buta gender (genderless and gender-blind).

Masyarakat Indonesia pada waktu itu dianggap belum memahami dan belum dapat membedakan apa itu jenis kelamin dan gender. Terkait dengan penjelasan Handajani di atas, maskulinitas 
Indonesia erat kaitannya dengan rezim Suharto ketika banyak didapati perkumpulan atau grup pemuda yang secara terang-terangan menentang pemerintahan Suharto. Sejalan dengan pendapat Handajani, Udasmoro (2014:17) juga menekankan bahwa konten karya-karya di masa rezim Suharto dikuasai oleh negara dan penulis tidak memiliki kebebasan untuk mengkritik negara dan atau resisten terhadap kebijakan negara.

Bertolak pada pemaparan argumen di atas, maskulinitas dan gender juga kerapkali berbenturan dengan stereotipe laki-laki dan perempuan yang ada dalam masyarakat. Kata 'stereotipe' mulai banyak digunakan pada abad ke-20 terutama di bidang sosiologi. Blum (2004) menjelaskan secara umum, stereotipe dan pemberian stereotipe sama halnya dengan 'mengutuk' apa yang telah ditandai sebagai karakter dan mempunyai kesan negatif. Dyer (1999) yang lebih dulu menulis mengenai hal tersebut, memaparkan bahwa stereotipe pada masa kini 'almost always a term of abuse'. Pemaparannya berkaitan dengan kelompok perempuan, gay, kulit hitam, yang sering dijadikan percontohan stereotipe dalam diskusi sehari-hari maupun melalui media massa.

Dalam kajian sastra remaja, stereotipe tidak lepas dalam konten cerita. Sebagai tahapan kehidupan yang dijalani setiap manusia, remaja adalah masa kritis seseorang dalam pencarian jati diri dan identitas yang akan dilakukan secara terus menerus. Hal ini sesuai dengan apa yang dikatakan Jenkins (2008:5) bahwa identitas adalah kapasitas manusia untuk bertanya tentang 'siapa' dan 'apa' dan melekat dengan setiap tindakan yang dilakukan seorang individu. Konsep subjektivitas dan identitas terkait erat dan secara virtual tidak dapat dipisahkan. Subjektivitas mengacu pada kondisi menjadi seorang pribadi dan proses menjadi pribadi, yaitu bagaimana subjek dibentuk. Sebagai subjek, seorang pribadi 'terikat kepada' proses-proses sosial yang menciptakan seseorang menjadi 'subjek untuk' dirinya dan orang lain. Repertoir kultural bagi diri di dunia Barat mendeskripsikan seseorang memiliki diri sejati, suatu identitas yang dimiliki dan yang dapat dikenali. Identitas diekspresikan melalui berbagai bentuk representasi yang dapat dikenali oleh orang lain dan diri sendiri. Jadi, identitas adalah suatu esensi yang dapat dimaknai melalui tanda-tanda selera, kepercayaan, sikap, dan gaya hidup (Barker 2008: 173-174).

Barker menjelaskan lebih jauh (2008:174-175), identitas dianggap bersifat personal sekaligus sosial dan menandai seseorang sama atau berbeda dengan orang lain. Dapat dikatakan bahwa orang memiliki 'esensi' diri yang disebut dengan identitas. Esensialisme berasumsi bahwa deskripsi tentang diri mencerminkan suatu identitas esensial. Berdasarkan logika ini maka akan ada esensi feminitas, maskulinitas, Asia, remaja, dan segala kategori sosial lainnya. Sebaliknya, identitas bersifat kultural dalam 'segala aspeknya', bersifat khas sesuai dengan ruang dan waktu tertentu. Ini berarti bentuk identitas dapat berubah dan terkait dengan berbagai konteks sosial dan kultural. Gagasan bahwa identitas bersifat plastis dipertegas oleh argumen yang disebut dengan antiesensialisme. Identitas bukanlah benda melainkan suatu deskripsi dalam bahasa. Identitas adalah konstruksi diskursif yang berubah maknanya menurut ruang, waktu, dan pemakaian.

Dari penjelasan di atas terlihat bahwa ada pola-pola yang dibentuk secara linear dalam konteks sosial maupun dalam karya sastra di mana menjadi laki-laki dan menjadi perempuan bukan hanya persoalan biologis tetapi merupakan bentukan situasi sosial dan rejim tertentu. Para remaja sendiri, adalah hasil dari bentukan tersebut. Bagaimana mereka merespon dinamika peran dan hubungan gender tidaklah bersifat stagnan. Ada pola-pola yang di satu sisi hampir sama, yakni persoalan kesadaran bahwa ada sesuatu yang normatif yang harus diikut tetapi di sisi lain ada kesadaran lain, yakni kesadaran bahwa ada yang berubah dari yang normatif tersebut. Bagaimana para remaja merespon dinamika persepsi yang berseberangan tersebut serta pendapat mereka mengenai posisi mereka dalam hal tersebut serta bagaimana wacana di dalam sastra sendiri menjelaskan posisi lakilaki dan perempuan menjadi fokus dari tulisan ini. Tujuan dari tulisan ini adalah untuk membenturkan teks sebagai salah satu wacana yang dibaca oleh para remaja dengan pendapat mereka tentang konstruksi laki-laki dan perempuan itu sendiri menurut mereka dalam konteks sosial. 


\section{Metode Penelitian}

Metode penelitian dalam riset ini adalah menelaah konstruksi gender dari buku bacaan remaja, dalam meneliti pandangan para remaja tentang konstruksi laki-laki dan perempuan. Lebih lanjut, peneliti ingin meneliti bagaimana konstruksi gender menurut remaja dalam konteks sosial.

\section{Hasil Penelitian dan Pembahasan}

\section{Normativitas gender dalam sastra remaja}

Berkaitan dengan gender dalam konstruksi sosialnya juga kerap mengalami stereotipe atau penggeneralisasian yang menghubungkan satu kelompok dengan sifat tertentu. Contoh yang diberikan oleh Blum (2004) misalnya orang kulit hitam pemalas, seorang perempuan cenderung emosional, orang Asia pintar matematika, dsb. Contoh tersebut yang kemudian dikategorikan sebagai stereotipe yang salah (false) dan menyesatkan (misleading) karena tidak semua orang kulit hitam pemalas, seorang perempuan belum tentu emosional, dan tidak semua orang Asia pintar matematika, dsb. Gender sebagai konsep sosial juga dikenali stereotipe yang belum sepenuhnya benar. Dalam penelitian ini contoh data lainnya diambil dari novel remaja Lupus Kecil Klasik (2013).

Pada halaman 23 (Lupus Kecil Klasik 2013) tertulis;

Ibu Lupus bersama ibu-ibu tetangga lainnya, suka ikut kegiatan semacam Dharma Wanita. Lupus sendiri kurang begitu tau, apa nama kegiatan itu sebenarnya. Pokoknya, mereka suka mengadakan kumpul-kumpul, seminar menjadi ibu yang baik, atau sekadar mengobrol.

Dalam kutipan tersebut, dimunculkan stereotipe ibu-ibu rumah tangga sebagai perempuan yang gemar berkumpul sembari ngerumpi dan ngobrol ngalor-ngidul. Walaupun nama organisasi resminya ditulis 'Dharma Wanita' hal ini menunjukkan kesan yang mengkritik secara tidak langsung terhadap kegiatan tersebut. Kegiatannya dianggap kurang begitu jelas dan hanya kumpulkumpul sambil sesekali mengadakan seminar. Remaja pembaca novel tersebut mungkin tidak akan terlalu menghiraukannya, namun biasanya yang justru terbersit dalam pikiran pembaca adalah kegiatan Dharma Wanita kurang begitu penting dan tidak ada urgensinya. Contoh lain terdapat pada kutipan tersebut,

Pernah juga karena tidak ada topik menarik, lalu ibu-ibu yang tergabung IWAPI (Ikatan Wanita Penyebar Isyu) sibuk berpantun-ria. (Lupus Kecil Klasik 2013: 113).

Stereotipe lain dihadirkan di sini bahwa kebiasaan perempuan yang senang bergosip tidak dihentikan ketika mereka sudah menjadi ibu, bahkan sindiran diberikan dengan disebutkannya nama organisasi IWAPI. Hal ini juga terulang di hal. 273 yang masih menyoroti kegiatan Mami Lupus di luar rumah:

Lupus dan Lulu mengamati dari kejauhan. Sementara Mami terus asyik ngobrol. Ibu-ibu kalo sudah kena kebiasaan seperti ini bisa lupa segalanya. Ngobrol memang mengasyikkan. Yang diobrolin Mami kalo nggak tentang arisan pasti tentang lomba gerak jalan ibu-ibu yang seragamnya harus dibeli sendiri-sendiri itu.

Meskipun demikian, melalui tokoh Lupus, kutipan tersebut disanggah kembali dengan isi sebagai berikut,

Tapi menurut Lupus, ada untungnya juga Ibu ikut perkumpulan seperti itu.

(Lupus Kecil Klasik 2013: 24). 
Pada kutipan ini terlihat posisi Lupus yang menjelaskan bahwa meskipun ibu rumah tangga, perempuan sebaiknya tetap memiliki kegiatan positif dan berada di luar rumah untuk sementara waktu. Wawancara singkat dilakukan kepada empat ibu rumah tangga berusia 29-30 tahun yang memiliki 1-2 anak menjelaskan hal tersebut. Sebagai ibu rumah tangga dan perempuan yang berada dalam usia produktif, pilihan untuk menjadi ibu rumah tangga awalanya dilakukan karena terpaksa. Tiga dari perempuan tersebut berada di negara Eropa dan satu di Indonesia yang kesemuanya tidak memiliki pengasuh bayi/anak ketika anak mereka dilahirkan. Sulitnya mencari pengasuh yang sesuai dan kekhawatiran akan isu pengasuh di luar membuat mereka memilih tinggal di rumah dan menjaga anak selain karena suami pun mengamini. Keempatnya bisa dibilang dalam kondisi keluarga menengah ke atas dan tidak terlalu memikirkan kebutuhan rumah tangga sehari-hari. Namun keempatnya tetap berkeinginan dan bermimpi untuk dapat bekerja dan beraktivitas kembali di luar rumah menggeluti pekerjaan yang biasa mereka lakukan sebelum menikah atau sebelum mempunyai anak. Kedua dari mereka merupakan lulusan universitas luar negeri jenjang S1 dan S2, ada yang pernah dan masih menjadi penerjemah freelance, penyanyi jazz yang cukup terkenal atau pernah bekerja di lembaga swadaya masyarakat asing.

Dari kutipan singkat tersebut tersirat dukungan kepada kaum ibu yang diwakilkan oleh tokoh Ibu Lupus bahwa ibu rumah tangga juga berhak berkiprah di luar rumah. Hal tersebut berusaha dimasukkan sebagai nilai sosial yang diharapkan dapat dicermati remaja pembaca karya. Berdasarkan asumsi, remaja pembaca karya tidak akan langsung memahami karya-karya yang mereka baca saat itu juga. Ada yang memahaminya keesokan harinya, di minggu berikutnya, sebulan kemudian, setahun, atau mungkin tiga puluh tahun kemudian. Menurut Janet Alsup (2010:205), pemahaman remaja terhadap konten cerita sastra remaja atau young adult literature berdampak pada bagaimana remaja memiliki persepsi diri dan konsep diri (self-perceptions and self-concepts) karena tulisan atau konten cerita sedikit banyak akan dihubungkan dan menghubungkan remaja dengan karakter dan peristiwa yang mereka alami serta identitas yang sedang dikembangkan (burgeoning identity) atau mungkin mempengaruhi perilaku mereka di dunia nyata.

Karya sastra sebagai cerminan masyarakat pada masanya, begitu pula karya sastra remaja. Penjelasan singkat mengenai novel yang digunakan di atas adalah Lupus Kecil Klasik terdiri dari tiga kumpulan buku: Lupus Kecil yang pertama kali diterbitkan Februari 1989, Sunatan Masal terbit Januari 1990, dan JJS: Jalan-Jalan Seram yang terbit pada Juli 1991. Di setiap bagian cerita atau buku terdiri dari sepuluh cerita pendek mengenai keseharian Lupus di sekolah, di rumah, dan ketika bermain dengan teman-temannya. Jika di seri remaja, Lupus diceritakan dekat dengan Boim dan Gusur; di buku Lupus Kecil Klasik teman-teman Lupus lebih beragam yaitu: Pepno, Happy, Uwi, Iko-Iko, Tono.

Di buku ini, keluarga Lupus juga masih lengkap, ada Mami, Papi, dan Lulu, adik perempuannya yang suka ngomong cadel meski tidak cadel. Lupus sendiri masih duduk di bangku sekolah dasar kelas satu dan berumur tujuh tahun. Perilaku keseharian keluarga Lupus dan teman-temannya di sekolah yang menjadi daya tarik buku ini. Kejahilan dan keisengan Lupus dan Lulu, kehebohan Mami mencoba resep baru dan Papi yang terkenal pelit dengan alasan hidup irit dan Pepno serta teman-teman yang kocak memberikan hiburan tersendiri ketika membaca buku ini.

Tahun 90-an dikenal dengan tahunnya istilah yang masih sering digunakan orang dewasa yang merupakan remaja pada masa itu. Istilah yang beken seperti EGP (Emang Gue Pikirin), PNY (Penasaran Ni Ye) atau teka-teki secara spontan dilontarkan dalam dialog tokoh yang jika dikaitkan dengan remaja saat ini, belum tentu mereka familiar dengan bahasa tersebut. Istilah dalam bahasa juga bisa dijadikan studi tersendiri ketika saat ini remaja lebih cenderung familiar dengan kata-kata 'ya keleeeus', 'hashtag', 'repath ya', 'ritwit', dsb.

Hal yang sedikit mengusik adalah pada buku pertama Lupus Kecil sebutan Ibu-Bapak digunakan untuk memanggil orang tua Lupus tetapi buku kedua dan ketiga digunakan sebutan Mami-Papi. Berdasarkan asumsi dari tulisan ini, sebutan tersebut berkaitan dengan munculnya penulis kedua 
pada buku kedua yang membawa warna baru dalam konten cerita Lupus, buktinya sejak buku kedua tersebut hingga buku paling akhir serta dalam film maupun serial Lupus yang pernah tampil di televisi, Lupus selalu menyebut 'mami' untuk memanggil ibunya.

Dari awal pembacaan novel remaja ini, sudah jelas tertulis perbedaan seks dan gender yang ditampilkan.

Berkokok satu, berkokok semua. Bertelur satu, bertelur semu...eh, enggak ding. Yang jantan kan enggak bisa bertelur, ya? (Lupus Kecil Klasik, 2013: 11).

Kutipan ini senada dengan jawaban responden remaja yang kami wawancarai bahwa perbedaan awal laki-laki dan perempuan sama seperti membedakan jantan dan betina pada hewan. Kodratnya pun harus tetap dijalani, mengandung lalu melahirkan atau bertelur/beranak. Peran anak dan identitas yang dibangun kemudian dimunculkan kemudian ketika anak atau sebagai remaja sudah dapat membedakan hal dasar. Hal ini terlihat pada kutipan berikut,

\begin{abstract}
Lupus kecil sudah merasa besar. Ia ingin punya kamar sendiri. Tidak lagi disatukan sama Ibu dan Bapak di sebuah kamar besar di pusat rumah. Tidak lagi bersebelahan dengan ranjang Lulu yang bentuknya mirip rumah boneka. Itu bagus, kata Bapak. Seorang anak, apalagi laki-laki, memang harus tidur terpisah dari orang tua. Belajar berani. Belajar mandiri, mengatur kamarnya sendiri. Dan Ibu pun mengabulkan permintaan Lupus. (Lupus Kecil Klasik, 2013: 21).
\end{abstract}

Di usia tujuh tahun, Bapak Lupus sudah menegaskan bahwa seorang laki-laki harus berani mandiri karena kelak akan hidup terpisah dari orang tua. Pelajaran ini dimulai dari pengaturan kamar tidur dan pembedaan kamar untuk anak laki-laki dan anak perempuan. Ibu Lupus juga terbukti ikut mendukung sepenuhnya. Dari kutipan ini terlihat jelas adanya harapan budaya dalam konteks sosial masyarakat patriarkal. Perempuan yang diwakilkan Lulu dan Ibu serta laki-laki diwakilkan Lupus dan Bapak. Anak perempuan cenderung dikaitkan dengan hal yang manis dan lucu (...ranjang Lulu bentuknya mirip rumah boneka) dan anak laki-laki disyaratkan harus mandiri karena kelak akan hidup tidak bergantung pada orang tua. Bapak dalam hal ini dianggap sebagai eksekutor mengambil keputusan untuk menyetujui anak laki-lakinya berhak tidur sendiri atau tidak sementara Ibu masih dituliskan sebagai penerus keputusan, memfasilitasi kebutuhan anaknya.

Kedua kutipan tersebut di atas juga disetujui oleh responden remaja yang mengaku sudah mempelajari teori dasarnya melalui sosiologi dan melihat contohnya di kehidupan nyata. Bahwa perempuan dikatakan ideal ketika perempuan tersebut sudah melakukan perannya sebagai "wanita" sama halnya dengan laki-laki. Ada hak dan kewaijban serta peran tertentu yang belum/tidak ada ketika seorang perempuan belum mencapai fase "wanita" dan ditambahkan tanggung jawab serta wibawa bagi kaum laki-laki. Memang, dalam hal ini tampak pemahaman remaja mengenai sebutan 'cewek' dan 'wanita' lebih menekankan pada hak dan kewajiban seseorang dalam berperan di ranah sosial. Ketika peran tersebut ditukar atau diubah, tidak semua responden remaja lantas menyetujui bahkan contohnya dalam kedua kutipan di novel Lupus Kecil Klasik. Kutipan pertama menegaskan boneka erat kaitannya dengan perempuan dan tidak mungkin anak laki-laki mau diberi boneka sebagai kado. Dalam isi cerita tersebut Pepno, teman Lupus, sedang berulang tahun dan Lupus mau memberikan kado. Lupus meminta usul Lulu yang saat itu sedang bermain boneka Barbie.

Lulu mengusulkan agar Pepno diberi boneka saja. Lupus jelas menolak. "Pepno kan anak laki-laki. Mana mau dia diberi boneka?” (Lupus Kecil Klasik, 2013: 52).

Remaja tahun 90-an pasti akan terngiang jelas masa kejayaan Barbie, salah satu nama boneka yang digambarkan memiliki kesempurnaan yang diidamkan kebanyakan perempuan, yaitu berambut pirang, tinggi semampai, berbadan langsing, cantik, dan memiliki segalanya. Boneka Barbie yang dikeluarkan oleh rumah produksi Mattel Inc. pada tahun 1959 mulai merambah Indonesia dan 
booming sekitar akhir 80-an dan tahun 90-an. Ikon Barbie juga sering dikaitkan dengan warna merah muda (pink) dan dihubungkan dengan dunia mode masa kini. Namun gambaran yang kurang membumi juga kerap menjadikan Barbie sebagai imej tidak nyata apabila diterapkan pada remaja atau kaum perempuan. Selain boneka Barbie, pita rambut juga dianggap berhubungan dengan perempuan dan dengan tegas Lupus dilarang memakainya oleh Ibu Lupus.

Kado ini ternyata tidak mau kalah saingan sama rambut Lulu yang senantiasa berpita. Lupus pun ikut-ikutan minta dipakaikan pita. Tapi Ibu melarang. Lupus nekat. Ia mengambil kaset dan mengeluarkan pitanya yang panjang. Kemudian digulungkan ke rambutnya. Lupus ternyata juga tak mau kalah saingan (Lupus Kecil Klasik, 2013: $55)$.

Aksesoris perempuan ini dalam kenyataannya tidak melulu dipakai oleh kaum perempuan. Kaum waria (wanita pria) juga kerap terlihat memakainya sebagai pelengkap dandanan à la perempuan. Dalam novel, Lupus diceritakan belum sepenuhnya mengerti arti aksesoris tersebut mengapa dipakaikan ke laki-laki atau perempuan. Walhasil dia tetap nekat memakai pita meski dari pita kaset. Sementara di kalangan remaja masa kini, aksesoris pita terutama yang banyak dipasarkan di toko-toko besar hanya diperuntukkan bagi perempuan saja. Hal ini juga yang menjadi penanda jelas dalam masyarakat patriarkal ketika ada seseorang yang sedikit melenceng atau berbeda dari kebanyakan akan dianggap mengingkari proses normalisasi seperti yang disebutkan Foucault.

Proses tersebut adalah penempatan hal yang dianggap normal dan tidak normal serta melekat erat dalam konsep identitas di kehidupan sehari-hari (Udasmoro, 2014: 31). Contohnya ketika para responden remaja ditanyai seputar perempuan tomboy, bagi mereka semua itu masih wajar. Bagi beberapa responden remaja perempuan ini kadang menguntungkan karena remaja perempuan tomboy lebih mudah dan simpel diajak berteman serta sering dipandang melindungi teman perempuan yang dianggap lemah. Remaja putri lainnya tidak mempermasalahkan apabila masih dalam batas kewajaran karena menganggap itu adalah fase sebelum menjadi 'wanita yang lebih feminin' dan yang terpenting bisa nyaman sebagai dirinya sendiri. Beberapa remaja laki-laki cukup menentang karena perempuan tomboy dia anggap menyalahi kodratnya sebagai perempuan yang seharusnya lemah lembut dan mengharapkan perempuan tomboy tersebut bisa bertingkah laku sewajarnya.

Dalam hal ini, secara tidak sadar para responden remaja tersebut menyimpulkan bahwa identitas perempuan tomboy masih ada kemungkinan bisa diubah. Remaja dikatakan sebagai agensi aktif yang berperan dalam pemilihan identitasnya dan dalam kapasitasnya bertindak sebagai individu. Jawaban para responden remaja ini menghubungkan agensi dengan kekuasaan/kekuatan (Loyal 2003:56-57) karena seorang individu memiliki kapasitas untuk bertindak secara bebas dan untuk menentukan pilihan mereka sendiri.

Ketika dihadapkan pada pertanyaan seputar waria, banci, serta metroseksual; pada awalnya mereka sempat berhenti sejenak memikirkan jawabannya. Ada yang menganggap waria dan banci hanya perbedaan istilah atau sebutan saja namun sama secara definisi dan dua dari responden belum tahu mengenai apa arti metroseksual. Susan Kuklin (2014) dalam bukunya yang berjudul Beyond Magenta: Transgender Teens Speak Out menggambarkan bagaimana enam remaja (transgender dan gender-neutral) yang dia wawancarai memahami, memilih, lalu kemudian memiliki preferensi gender.

Remaja dipilih sebagai responden dikarenakan preferensi gender mereka dianggap belum pasti dan masih bisa berubah. Selama perjalanan konstruksi identitasnya, gender menjadi salah satu yang dinegosiasikan dan diungkapkan secara tidak langsung dalam karya sastra, dalam hal ini novel remaja Lupus Kecil Klasik. Contoh yang telah disebutkan di atas adalah larangan Ibu kepada Lupus agar tidak memakai pita ketika akan pergi ke rumah Pepno menghadiri pesta ulang tahun. Selain itu Lupus yang diceritakan akan disunat juga menganggap anak perempuan lebih beruntung karena tidak harus melewati fase tersebut (Hilman 2013:134-135). 
Saat itu, Lupus merasa alangkah bahagianya jadi anak perempuan seperti Lulu. Tak perlu disunat. Dan anak lain yang menganggap peristiwa ini nggak istimewa, yaitu si Uwi. Abis dia nggak disunat sih... hihihi.

Wiegman (2007:218) mengungkapkan dari sudut pandang tertentu, gender merupakan efek dan alat dari heteronormativitas. Sebagai alat, gender merupakan sarana yang menaturalisasikan tubuh menjadi dua-pasang/bagian, masing-masing memiliki dampak, ambisi, dan kecenderungannya sendiri, masing-masing terkait pernikahan dengan yang bagian lainnya dalam konteks seksual maupun sosial, sebagai laki-laki dan perempuan.

Gender sebagai 'alat' atau 'sarana' banyak terdapat pada jawaban para responden remaja yang menganggap transgender merupakan ekspresi diri seseorang dan dilakukan karena ada tekanan ekonomi. Transgender dipandang salah secara moral dan agama di mata responden remaja karena pelakunya tidak bertindak sesuai kodrat dan takdir mereka. Para responden remaja tersebut mencermati perilaku laki-laki yang berusaha bersikap seperti perempuan baik dari sifat, bahasa tubuh serta pakaiannya dengan pandangan beragam. Sebagian besar menganggap hal tersebut sebagai pilihan beresiko yang dijalani seseorang selama tidak mengganggu kenyamanan orang lain. Pendapat lain menganggap hal tersebut sebagai gangguan kejiwaan dan memandang rendah (cenderung jijik dan takut) perilaku tersebut. Tuntutan profesi akibat keadaan ekonomi juga disebutkan sebagai alasan yang ada di dunia nyata karena menurut pandangan remaja, para transgender hanya terjebak dan terpaksa. Dari segi agama, satu responden remaja juga menimpali hal tersebut sebagai wujud kurang bersyukur kepada Tuhan dan tidak menghargai hidup yang telah diberikan. Pendapat tersebut juga diimbuhi dengan alasan Indonesia bukanlah negara bebas seperti di Amerika.

Gender sebagai efek merupakan alibi untuk pemaksaan kekerasan dari rancangan heteroseksual; alasan untuk segala jenis disiplin sosial, mulai dari pembagian kerja menurut jenis kelamin sampai ke larangan atau peraturan berdasarkan jenis kelamin. Terkait dengan pembagian kerja, novel remaja Lupus menyajikan representasi ibu rumah tangga, Mami, yang selalu ada di rumah berkutat dengan pekerjaan domestik. Tokoh Papi digambarkan sebagai kepala keluarga yang bertugas bekerja mencari nafkah di luar ranah domestik. Walau terlihat sebagai novel yang ringan, terdapat kritik yang ingin disampaikan kepada para laki-laki yang mencari nafkah terhadap istrinya sebagai ibu rumah tangga.

Selama ini Papi selalu bertanya-tanya tentang apa yang saya lakukan sepanjang hari. Nah, sekarang lihat, apa yang tidak saya lakukan sepanjang hari. Hahaha..." (Lupus Kecil Klasik, 2013: 276).

Dalam kutipan ini ditampilkan Mami Lupus yang ingin memberi pelajaran kepada Papi. Selama Papi bekerja dan sepulangnya dari kantor, Papi selalu menganggap Mami tidak melakukan apa-apa di rumah. Dari kutipan ini pesan moral yang ingin disampaikan adalah peran ibu rumah tangga dalam menjaga anak-anak, memasak serta membersihkan rumah dan sekitarnya sering dianggap pekerjaan sia-sia dan sepele. Rutinitas kerja domestik yang selalu berulang setiap hari dianggap sebagai pekerjaan domestik yang tidak ada artinya dari sudut pandang pekerja kantoran.

Gender sebagai efek terkait dengan sexual prohibition tampak dalam contoh transgender, kaum LGBT, perempuan tomboy, dan laki-laki metroseksual. Larangan tersebut berlaku dalam konteks normatif sosial masyarakat maupun konteks agama. Masyarakat atau kaum marjinal tersebut di atas jelas ada yang mengindahkan maupun tidak. Fenomena sosial masa kini memperlihatkan semakin terbukanya pemikiran remaja dalam melihat variasi gender tersebut di masyarakat. Contoh konkretnya adalah jawaban salah satu responden yang memaklumi namun tidak ingin dikatakan mendukung maraknya hal tersebut. Dia mengatakan tetap bisa nyaman melihat keragaman dan dinamika masyarakat jaman sekarang. Lebih jauh lagi, ada pelajaran yang bisa dia dapatkan dari keragaman masyarakat tersebut. 
Adanya variasi gender dalam masyarakat yang terwujud melalui sebutan 'banci' dan 'waria' dipandang secara tumpang-tindih oleh para responden remaja. Sebagian besar menjawab 'waria' dan 'banci'adalah wanita setengah pria atau pria yang berdandan seperti wanita dengan tubuh yang dibentuk sedemikian rupa seperti perempuan dan suka menggoda laki-laki., namun kata 'banci' mereka anggap lebih kasar konotasinya. Pekerjaan 'waria' disamaratakan seperti perempuan penghibur di klub malam dan lebih bergengsi namun 'banci' konotasinya cenderung lebih kampungan dan kasar. Responden remaja lain memahami waria sebagai bagian dari gender yang melenceng, sebagai bagian dari penemuan jati diri dan identitasnya. Ada yang menganggap kelompok tersebut sebagai orang yang belum yakin akan kepribadiannya dan siapa dirinya.

Jika beberapa remaja ada yang beranggapan kelompok transgender dengan 'banci' sama, di sisi lain ada yang memahami 'banci' sebagai laki-laki feminin, sensitif, yang sifatnya lemah lembut, bahasa tubuh seperti perempuan dan gemar bergosip atau sekedar nongkrong dengan teman-teman perempuan. Sebutan ngondek atau 'melambai' juga ditambahkan pada kelompok tersebut. Dua responden remaja beralasan minimnya interaksi dengan laki-laki dalam keluarga atau rasa nyaman berteman dengan laki-laki mengakibatkan tidak adanya role model laki-laki yang masuk di kehidupan mereka.

Koeswinarno (2004:73) menuliskan bahwa kehadiran waria merupakan sebuah proses historis. Pembentukan kepribadian waria merupakan proses yang cukup panjang, dimulai dari masa anakanak hingga menginjak masa remaja. Munculnya fenomena waria ini tidak lepas dari konteks cultural. Kebiasaan-kebiasaan ketika dibesarkan di dalam keluarga, kemudian mendapat penegasan pada masa-masa remaja, menjadi penyumbang terciptanya waria. Apabila dicermati, pembentukan waria dikatakan Koeswinarno sudah bisa dilihat semenjak mereka menginjak masa remaja, namun orang tua tidak pernah menyadari atau justru mengingkari (denial). Orang tua yang sibuk akan cenderung menuruti permintaan-permintaan anaknya terhadap barang-barang yang 'anak perempuan' tidak sesuai dengan mereka.

Koeswinarno (2004:76-77) menegaskan bahwa presentasi perilaku anak 'sebagai perempuan' yang tidak pernah disadari orang tua atau keluarga, pada gilirannya aka direspons ketika kesadaran itu muncul secara timbal balik atau setelah mengetahui adanya perilaku-perilaku tertentu yang dianggap menyimpang. Respons ini muncul biasanya setelah anak dengan sangat reaksioner, berani memakai atribut-atribut perempuann, misalnya bedak, lipstick, sampai pakaian perempuan. Semula tindakan memang dilakukan secara sembunyi, namun biasanya dorongan 'menjadi perempuan' lebih besar.

Dorongan 'menjadi perempuan' namun tetap bersikap laki-laki bisa mengarah pula kepada kaum metroseksual. Istilah ini banyak bermunculan di golongan urban dengan ciri-ciri laki-laki eksekutif perlente, klimis, wangi, dan sangat menjaga penampilan. 'Menjadi perempuan' bagi laki-laki metroseksual biasanya hanya dilihat dari cara mereka berpakaian dan penampilan sehari-hari yang rapi dan masih ada yang tetap menonjolkan sisi maskulin mereka. Gaya dalam berpakaian (fashion style) laki-laki metroseksual biasanya juga didukung oleh tuntutan profesi di daerah perkotaan. Merk (brand) dan mode tertentu biasanya sering diikuti para laki-laki metroseksual perkotaan, sebut saja Pull\&Bear, TopShop for Man, H\&M, Zara Man, dan sederet brand asing lainnya. Pemakaian brand tertentu juga dapat dikatakan sebagai usaha mereka untuk tetap eksis di pergaulan urban atau kelompok sosialita tertentu. Apabila brand asing digunakan sebagai pakaian sehari-hari, hasil desain dari para perancang kenamaan Indonesia juga tak lepas dijadikan sebagai pendukung gaya berpakaian laki-laki metroseksual. Desainer Indonesia seperti Barli Asmara, Tex Saverio, Ghea Panggabean, Oscar Lawalata, Obin, dan lainnya kerap mengeluarkan hasil rancangan yang dianggap sesuai dengan kaum urban masa kini, termasuk didalamnya laki-laki metroseksual. Contoh yang diberikan responden remaja ini adalah artis-artis K-Pop seperti EXO, SuJu, DBXQ yang saat ini sering menjadi kiblat mode remaja laki-laki masa kini. Karena terlalu memperhatikan penampilan dan terkadang lebih repot daripada perempuan, para responden remaja juga berpendapat sebagian besar laki-laki metroseksual memiliki orientasi seksual yang menyimpang. 


\section{Gender dan identitas di kalangan remaja}

Aplikasi teori tersebut di atas tidak lengkap tanpa data yang sesuai. Selain pengumpulan data dari studi literatur dalam novel remaja Lupus Kecil Klasik (2013) yang diterbitkan kembali, kami juga telah mewawancara 13 responden yang kesemuanya remaja (laki-laki dan perempuan) dan masih duduk di bangku SMP atau SMA. Responden berusia 13-17 tahun yang dianggap mewakili sudut pandang remaja mengenai identitas dan gender. Pertanyaan yang diajukan kepada 13 responden itu berkaitan dengan gender di mata remaja: apa definisi laki-laki dan perempuan bagi mereka, bagaimana laki-laki dan perempuan yang ideal menurut mereka, apa definisi perempuan tomboy, banci, waria, dan metroseksual menurut mereka, serta pendapat mereka secara keseluruhan mengenai hal tersebut.

Di awal wawancara, tim memberikan penjelasan mengenai alasan wawancara tersebut dan tidak semuanya bersedia datanya dilampirkan dalam wawancara tersebut. Pemilihan kata juga harus dilakukan oleh pewawancara dan disesuaikan dengan kosakata yang sering digunakan oleh para responden. Kata laki-laki dan perempuan disubstitusi menjadi kata 'cowok' dan 'cewek' karena dianggap lebih lazim digunakan di kalangan remaja. Wawancara selain dilakukan secara langsung juga dilakukan melalui jalur komunikasi LINE. Ini adalah aplikasi media sosial yang berfungsi seperti Whatsapp dan BBM, yang dapat digunakan untuk berkomunikasi seperti chatting, mengirim foto, lagu, atau film.

Beberapa responden yang kami wawancara menjawab bahwa laki-laki dan perempuan dibedakan berdasarkan kodrat dan kewajiban mereka. Perempuan ada untuk mengandung, melahirkan serta mengurus rumah tangga, seseorang yang disiapkan sebagai seorang ibu, bersikap lembut, dan pengertian sementara laki-laki selain menjadi ayah, harus mencari nafkah untuk menopang keluarga dan melindungi keluarganya. Dari jawaban-jawaban tersebut tampak jelas gambaran umum laki-laki dan perempuan di mata remaja masih sekedar kodrat alamiah sebagai penerus keturunan manusia.

Keunikan responden selanjutnya adalah membedakan sebutan 'cewek' yang baginya hanya lazim diberlakukan untuk kelompok perempuan berumur belasan sampai pertengahan 20-an dan 'wanita' adalah kelompok perempuan berusia 28 tahun ke atas. Mereka memiliki perilaku-perilaku tertentu dan diberi label tertentu dalam masyarakat. Seorang 'wanita' dan 'pria' dalam pandangan remaja adalah seorang dewasa yang sudah berpikiran maju, bekerja, dihormati, dan berwibawa. Kelompok 'wanita' dan 'pria' ini dianggap dapat bersikap dewasa dan tenang dalam menghadapi masalah. Dari wawancara ini pula didapatkan bahwa orang dewasa dalam pandangan remaja adalah orang yang dapat berinteraksi dengan siapa saja tanpa pandang bulu dan dapat membedakan yang baik dan buruk untuk dirinya. Mereka juga menyiratkan bahwa orang dewasa selayaknya bisa menjaga sikap di depan orang namun mengharuskan tetap bersikap easy going, punya banyak relasi dan teman serta bertanggung jawab dan dipercaya.

Karakter laki-laki dan perempuan dimunculkan pada jawaban responden ketiga yang menyebutkan bahwa perempuan cenderung sensitif, ribet, dan self-conscious sementara laki-laki akan bertindak lebih santai, simpel dan jarang overthinking. Hal ini akan menjadi perkecualian bagi kelompok laki-laki yang bertingkah laku seperti perempuan. Perilaku ribet dan simpel dicontohkan mereka dalam keseharian ketika akan mandi maupun ketika akan bepergian. Perempuan digambarkan cenderung repot dengan barang-barang bawaannya dan sibuk berdandan sebelumnya. Perbedaan dari sisi biologis juga dituturkan oleh responden remaja. Laki-laki dan perempuan memiliki tanda akhil baligh yang berbeda, untuk laki-laki tidak akan terlalu kentara namun perempuan ditunjukkan dengan 'datang bulan' yang biasanya diperoleh lebih dulu daripada remaja laki-laki.

Responden juga menambahkan bahwa perempuan adalah ciptaan Tuhan yang indah dan halus serta bisa membuat laki-laki luluh dan laki-laki dituntut untuk kuat dan tangguh. Bagi para remaja ini, perempuan seharusnya feminin dan bossy dalam artian lebih bertanggung jawab dari laki-laki walau sebagian dari mereka menganggap pemimpin selayaknya adalah kaum laki-laki. Responden 
remaja laki-laki yang diwawancarai memandang perempuan sebagai mahluk yang butuh waktu, butuh perhatian tinggi, dan kesetiaan serta pendamping laki-laki. Dalam hal ini penuturan sesuai dengan buku Sex and Gender yang ditulis oleh Hilary M. Lips (2007) bahwa terdapat harapanharapan budaya terhadap laki-laki dan perempuan yang mengharuskan laki-laki bersifat kuat dan perempuan bersifat lemah lembut.

Konstruksi sosial dan pengaruh budaya dalam masyarakat menjadi beberapa faktor yang mendefinisikan gender. Tidak mengherankan definisi gender pun beragam dan menyesuaikan kondisi lingkungan tempat laki-laki dan perempuan berada. Gender dipandang sebagai konsep kultural dapat berubah-ubah dengan melihat tingkah laku dan peran laki-laki maupun perempuan serta nilai mereka dalam masyarakat. Sudut pandang remaja sebagai bagian dari masyarakat sosial menilai bagaimana sebaiknya laki-laki dan perempuan bertingkah laku. Para remaja juga berpendapat bahwa perempuan lebih memakai perasaan dan laki-laki mengedepankan rasio dalam bertindak. Mereka memberikan contoh sepasang kekasih remaja, ketika perempuan lebih cenderung diam dan bertingkah beda ketika sedang bertengkar, laki-laki akan bertanya langsung alasannya: mengapa, bagaimana, kapan, dsb.

\section{Simpulan}

Bagi para remaja maupun pembaca novel remaja, gender dan identitas tidak secara sadar mereka pahami. Gender yang didefinisikan terkait dengan konteks sosial dan kultural remaja dapat mempengaruhi proses konstruksi identitasnya. Dalam konteks karya sastra dan praktik sosial remaja sendiri, terlihat bahwa ada satu aspek yang terus dipercayai dan masuk dalam kognisi para remaja, seperti halnya dalam pemikiran tokoh maupun pengarang dalam Lupus bahwa ada hal-hal normatif terkait gender yang terus menerus direproduksi. Laki-laki dan perempuan adalah bentukan yang terus dipertanyakan oleh Lupus untuk menjelaskan bukan untuk mengkritisi perempuan atau laki-laki itu sendiri tetapi justru untuk memperkuat norma yang ada bahwa memang perempuan dan laki-laki sudah memiliki bagian-bagian yang harus diisi dengan gender role mereka.

Normativitas itu juga dilakukan oleh para remaja dalam praktik sosial mereka yang semakin meneguhkan situasi bahwa antara yang dipikirkan, dilakukan dan dialami adalah tiga hal yang berbeda. Para remaja memiliki pemikiran normatif yang ingin ditekankan. Akan tetapi karena mereka mengalami dalam kehidupan sehari-hari persinggungan dengan kebenaran-kebenaran gender yang lain, maka ruang-ruang bagi kebenaran yang lain itu sering turut terbuka meskipun selalu usaha terus menerus untuk menekankan bahwa seharusnya mereka tidak melakukannya.

\section{Daftar Pustaka}

Alsup J (2010) Female reading YAL: Understanding Norman Holland's identity themes thirty years later. In Alsup J (ed). Why are teens reading YAL? Young Adult Literature and adolescent identity across cultures and classrooms. New York: Routledge.

Barker C (2008) Cultural studies: Theory and practice. London: Sage Publications.

Blum L (2004) Stereotypes and stereotyping: A moral analysis. Philosophical Papers Vol. 33 (3) :251-289.

Dyer R (1999) The role of stereotypes. In Marris P and Thornham S (ed). Media studies: A reader, $2^{\text {nd }}$ Edition. Edinburgh: Edinburgh University Press.

Green J (2005) Looking for Alaska. Boston: Dutton Juvenile.

Handajani S (2010) Selling alternative masculinities, representations of masculinities in Indonesia men's lifestyle magazines. Thesis PhD. Unpublished. School of Social and Cultural Studies: The University of Western Australia.

Hilman \& Boim (2013) Lupus kecil klasik. Jakarta: Gramedia.

Hunt P (ed) 2005. Understanding children's literature, $2^{\text {nd }}$ ed. London \& New York: Routledge.

Jenkins R (2008) Social identity, Third Edition. London and New York: Routledge. 
Koeswinarno (2004) Hidup sebagai waria. Yogyakarta: LKiS.

Kuklin S (2014) Beyond magenta: Transgender teens speak out. US: Candlewick Press.

Lips HM (2007) Sex and gender. Australia \& New Zealand: McGraw-Hill Education.

Loyal S (2003) The sociology of Anthony Giddens. London: Pluto Press.

Mackey M (2011) Narrative pleasures in young adult novels, films and video games (Critical Approaches to Children Literature). London: Palgrave Macmillan.

Udasmoro W (2014) Konstruksi identitas remaja dalam karya sastra. Yogyakarta: Prodi Sastra Prancis, Fakultas Ilmu Budaya, UGM.

Wiegman R (2007) The desire of gender. In Haggerty GE \& McGarry M (ed). A companion to lesbian, gay, bisexual, transgender, and queer studies. United of Kingdom: Blackwell Publishing. 